\title{
Boli Trial and Japan's Bacterial Warfare
}

\author{
Sevsky Eergeevich \\ MBOU SOSH S. Aspen River, Khabarovsk city
}

\begin{abstract}
The article analyzes the Khabarovsk trial of Japanese war criminals during the Second World War. The inhumane activities of Detachment 731, created specifically for the development and testing of biological weapons. And also, the article examines the influence of the Tokyo and Khabarovsk processes and the experiments of the 731 squadron on the course of world history.
\end{abstract}

Keywords: unit 731, experiments, Khabarovsk trial, Shiro Ishii, Kwantung army, crimes, biological weapons

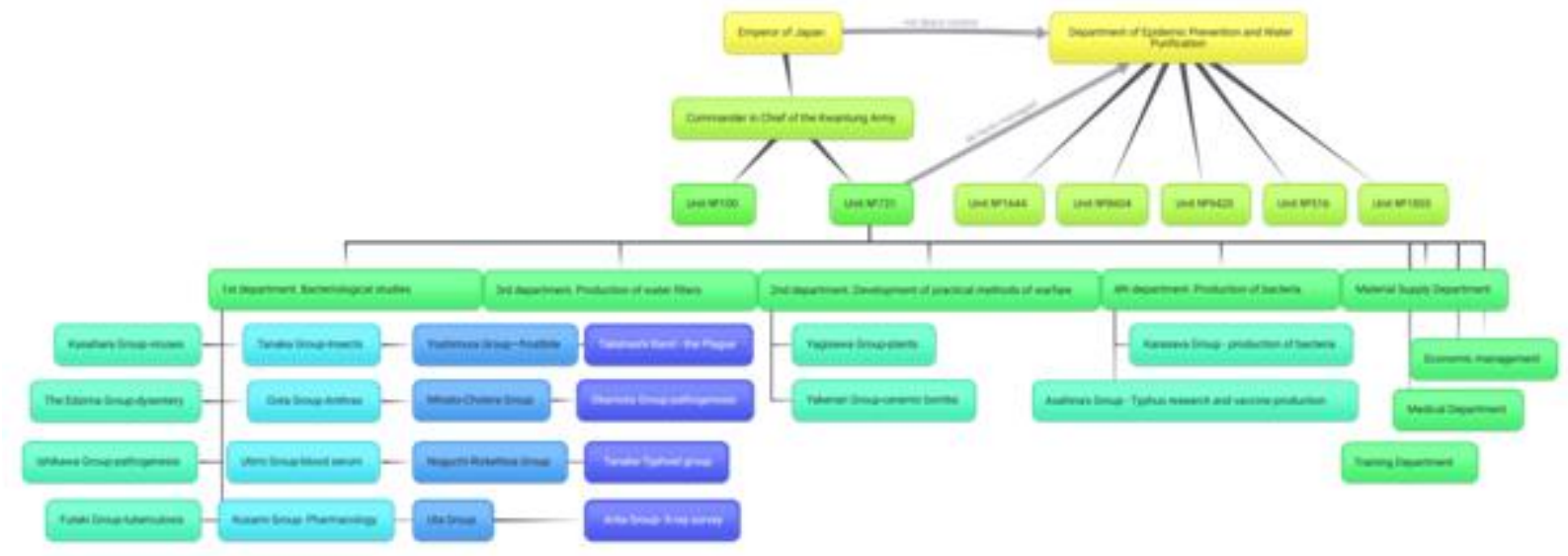

\section{731-The beginning}

After the end of the First World War in November 1918, the Japanese government began to consider the possibility of creating a series of projects aimed at developing and creating biological weapons for use in future military companies. The highest bodies of the Japanese government eventually approved these projects, and a research group of forty eminent scientists was founded, led by Dr. Shiro and led by Major Terunobu Hasebe.

The impetus in development took place in 1926 when Emperor Hirohito took the throne of Japan. The emperor's ideas about "scientific weapons" found support among the aggressive Japanese military. They understood that it was impossible to win a protracted war against the Western powers based on the samurai spirit and conventional weapons alone, therefore, on the instructions of the Japanese military department in the early 1930s, the Japanese colonel and biologist Shiro Ishii made a voyage through the bacteriological laboratories of Italy, Germany, the USSR, and France.

In his final report, presented to the highest military ranks of Japan, he convinced everyone present that biological weapons would be of great benefit to the Land of the Rising Sun.

Officially, Detachment 731 was called the "Main Base of the Water Supply and Prevention Directorate of the Kwantung Army Units" ${ }^{1}$ and was deployed in Harbin in 1933. Initially, to hide the true purpose of this formation, it was called the
"Kamo squad"2 [1]. This is a complex for the development of biological weapons. Japan was preparing for bacteriological warfare against the USSR, China, and the Mongolian People's Republic. The head of the research center was appointed Lieutenant General of the Imperial Japanese Army Shiro Ishii, who studied the plague infestation of fleas. In June 1938, by order No.1539 of the Kwantung Army Headquarters, a "Special Military Zone" was created. For the construction of the complex in 1932 near Harbin, near the village of Pingfang, a site was prepared, for which about 300 peasant houses were burned, the inhabitants of which were driven out into the street. The complex was placed in China for several reasons: firstly, if the materials were leaked, the population of another country would have suffered, and secondly, there were always experimental subjects nearby in China [2].

Detachment 731's complex consisted of more than 150 structures, including an airfield, living quarters, laboratories, a corpse incinerator, a vivarium for keeping test subjects, and other structures.

The special detachment consisted of four scientific departments, which were divided into 20 operational research groups. The number of employees of the special squad was 3, 607 people, of which 52 were surgeons, 38 nurses, 49 engineers, and 1, 117 military doctors. The visiting doctors and professors from Japan were interested in the rare opportunity to conduct human experiments and the strong financial support from the army. 
In addition to detachment 731 , there were other detachments for bacteriological research, which were controlled by the "Department of Epidemic Prevention and Water Purification" $^{1}$ : No.100 2 , No.1644 ${ }^{3}$, No.8604, No.94204, No. $516^{5}$.

The experiments of the 731 squadrons and, in particular, its specific members can claim the title of the most brutal experiments in world history.

The experiments of the detachment were aimed not only at the creation of biological weapons but also implied the study of human limits, and Japanese scientists understood this in an extremely specific way.

So, Dr. Hisato Yoshimura was responsible for research on frostbite, who conducted experiments on frostbite in the coldest months of the year, namely in November, December, January, and February. The anthrax was dealt with by Colonel Oota, a researcher from the first department, who infected his subjects through chocolates [3, 4]. The development, research, and application of the plague were handled by the first department, in particular, a group led by Takahashi Takaatsu. Futaki was engaged in the study of tuberculosis, which infected experimental subjects through injury with shrapnel infected with gas gangrene bacteria. Tanabe was responsible for the study of typhus, infection occurred through sweetened water and buns, and the latter was photographed and exhibited as an act of benevolence [4, 5]. The infection of the experimental subjects with syphilis occurred both to study contraceptives and to study the disease, but it could also be a consequence of banal rape [6, 7] [8,9]. A group led by Minato was responsible for cholera research. The Arita group was engaged in X-ray radiation, during the experiments, the experimental subjects were irradiated with a lethal dose of X-ray radiation $[10,11]$.

Thus, Japanese science developed microbiology, virology, surgery, anatomy, knowledge in physiology, in the mechanisms of pathogenesis, and this is only a small part on which the 731 squad had a tremendous influence.

\section{Khabarovsk War Crime Trial}

After the defeat of the Third Reich, all the attention of the Allied forces switched to Japan. So, on August 9, 1945, the Manchurian strategic offensive operation began, during which twelve war criminals were captured.

\footnotetext{
${ }^{1}$ Formation of the Imperial Japanese Army, formed in 1936 and disbanded in 1945, engaged in both the duties of maintaining sanitary standards in the Imperial Army and secret research in the fields of chemical and biological weapons.

${ }^{2}$ Studied the causative agents of infectious diseases and the possibility of destroying the cavalry of the Chinese and Red armies. ${ }^{3}$ Known for experiments on people, during which prisoners were artificially infected with cholera, typhus, bubonic plague.

${ }^{4}$ The largest special research unit of the Japanese army, located outside of China.

${ }^{5}$ Research in the field of chemical weapons. As a result of the experiments, a huge part of China was exposed to chemical contamination.
}

During the Potsdam Conference, the idea of convening an international military tribunal for the Far East was born. The Tokyo trial took place from May 3, 1946, to November 12, 1948, over military and political criminals [12].

After the Tokyo trial, the Khabarovsk trial took place in Khabarovsk from December 25 to December 30, 1949.

The Khabarovsk trial is a trial of a group of former servicemen of the Kwantung Army accused of creating and using bacteriological weapons during World War II, in violation of the International Geneva Protocol ${ }^{6} 1925$ on the prohibition of the use of asphyxiating, poisonous, or Other Similar gases and bacteriological agents in war, which entered into force on February 9, 1928 [12]. The Khabarovsk trial took place in the district House of Officers of the Soviet Army, now the House of Officers of the Eastern Military District [13].

The defendants in the trial were:

Yamada Otodzo (yap. 山田乙三) General, former commander-in-chief of the Japanese Kwantung Army. He directed the criminal activities of his subordinate detachments No.731 and No.100 [14].

Kazitsuka Ryuji (yap. 梶塚隆二) Lieutenant General.

Takahashi Takaatsu (yap. 高橋隆篤) Lieutenant General.

Kawashima Kyoshi (yap. 川島清) Major General.

Sato Shunji (yap. 佐藤俊二) Major General.

Nishi Toshihide (yap. 西俊英) Lieutenant Colonel.

Karasawa Tomio (yap. 柄沢十三夫) Major.

Onoue Masao (yap. 尾上正男) Major.

Mitomo Kazou (yap. 三友一男) is a non-commissioned officer.

Kikuchi Norimitsu (yap. 菊地則光) Corporal, former trainee nurse of Branch No.643 of Detachment No.731.

Hirazakura Zensaku (yap. 平桜全作) lieutenant.

Kurushima Yuji (yap. 久留島祐司) is a former nurselaboratory assistant of branch No.162 of detachment No.731. As can be seen, the composition of the defendants was very heterogeneous: from the general, the commander of the army, to the corporal and the nurse-laboratory assistant. This is because the personnel of detachment No.731, where the creation of bacteriological weapons was carried out, was almost completely evacuated to Japan, and the Soviet troops captured only some Japanese military personnel who were directly involved in the preparation and conduct of bacteriological warfare.

The indictment of the Commission during the process consisted of a Chairman, major General of justice Chertkov D. D, Colonel of justice Ilnitsky M. L., and Lieutenant Colonel of justice Vorobyov I. G. Also, the state prosecution was supported by the state counselor of justice 3rd class Smirnov, L. N.

The defense was represented by:

${ }^{6} \mathrm{https} / / / \mathrm{www}$. icrc.org/ru/doc/resources/documents/misc/protocolgases-170625.html 
Belov N. P., Sannikov C. E., Zverev A. V., Borovik N. K., J. P. Bogachev, V. P. Lukyantseva, Bolkhovitinov D. E., Prokopenko, G. K. [15, 16].

Witnesses of the Khabarovsk trial:

Tamura Tadashi [17], Ozeki Shigeo [18], Sasaki Kosuke [19], Segoshi Kenichi [20], Kurakazu Satoru [21], Tachibana Takeo [22], Furuichi Yoshio [23], Kanazawa Kazuhisa [24], Hotta Ryochiro [24], Mineoi Kiyashi [24], Saito Masateru [24], Fukuzumi Mitsuyoshi [24], Kuwabara Akira [24], Sakurashita Kiyoshi [24], Hataki Akira [24], Misina Takayuki [24], Zhukov-Verezhnikov H. H. [25], Colonel of the medical service Krasnov V. D., Head of the Department of Microbiology of the Khabarovsk Medical Institute Professor Kosarev H. H., associate professor of the same department Livkina E. G., lieutenant colonel of the Veterinary Service Alexandrov N. A., parasitologist Kozlovskaya O. L. [26].

\section{United States of America}

For the United States, the results of the Tokyo and Khabarovsk trials were successful, although the Americans lost their military due to 731 detachments ${ }^{1}$. Dr. Edwin Hill, head of Fort Detrick, spoke about this "success" for the United States ${ }^{2}$, the report ${ }^{3}$ stated that the information was "absolutely priceless"; it "could never be obtained in the United States due to doubts related to human experiments", and "the information was obtained quite cheaply" [27, 28]. The US used all available resources to get information about Japanese weapons.

So, in September 1945, Murray Sanders, a microbiologist, an employee of the American military center for biological weapons, arrived in Yokohama. Sanders was sent to create an investigation and interrogation of the main members of the 731 squad Naito Ryoichi, Junichi Kaneka, Chisada Masuda, and others, they formed the so-called "Sanders Report" [29].

A little later, on January 17, 1946, US Army Lieutenant Colonel Arvo Thompson was sent, who conducted the first interrogation in the Ishii mansion [30]. Thompson's investigation included studying the process of creating bacterial warfare units and training combat production facilities. In a couple of months, Thompson was able to get confirmation from Isia of the fact of human experiments and joint research with other forces, such as the Navy, in this area [31]. Based on this, in May 1946, Thompson wrote a "Report on Japanese Bacterial Weapons", in which he outlined the scale of research on bacterial weapons, methods of conducting bacterial warfare, etc.

And already on May 6, 1947, Douglas MacArthur wrote to Washington, DC that "additional data can be obtained by informing the Japanese involved that the information will be

\footnotetext{
${ }^{1} 186$ people died of typhoid fever [32].

${ }^{2}$ https://en.wikipedia.org/wiki/Fort_Detrick

${ }^{3}$ The report was presented to the Commander of the Allied Forces after an interrogation conducted jointly with Joseph Victor in October 1947.
}

stored in intelligence channels and will not be used as war crimes" [33].

In addition to all of the above, to finally eradicate doubts that Ishii collaborated with the United States, I want to quote Richard Drayton, a Doctor of History at Cambridge University, who says in his publication [34]:

"Japan's Dr. Shiro Ishii, who had experimented with prisoners in Manchuria, came to Maryland to advise on bioweapons."

After the outbreak of the Korean War in 1950, the US Army used biological and chemical weapons ${ }^{4}$, which was created by the data of the Japanese. So, official Han Xiao ${ }^{5}$, China and North Korea claimed that the bombs used by the US army are bombs of the "Uji System" [35]. There are also documents stating that Ishii traveled to the United States many times from 1950 to 1952 and founded an institution called "Tokyo Nutrition Research Center" (codenamed "J2C406") [36].

To summarize, the United States received at its disposal some of the best doctors in the world, experienced and educated researchers in the fields of microbiology, virology, and bacteriology, as well as the most up-to-date data on biological weapons at that time.

\section{People's Republic of China}

These events had the greatest impact on China, which is not surprising because the detachment was located in China, and the main test subjects were Chinese (of the order of 67\%) $[37,38]$, next, in terms of numbers, are the Russians (of the order of 30\%) [39, 40], after the Russians, Koreans (about $2 \%$ ) [41] and, finally, Mongols (about 1\%). The victims also included a small number of European, American, Indian, Australian, and New Zealand prisoners of war [42, 43, 44, 45].

The Chinese side lost the most people due to the activities of detachment 731, according to the most conservative estimates, at least 3, 000 people were killed directly, [46] at least 600 of which were provided annually by Kempeitai ${ }^{6}$ [47]. But the American historian Sheldon H. Harris claims that more than 200, 000 people died [48, 49], and another version of the number of dead was presented at the International Symposium on the Crimes of Bacteriological Warfare in 2002, held in Changde, China, as a result, a figure of about 580, 000 people was announced [50].

Also, Sheldon H. Harris documented that the victims tended to be political dissidents, Communist sympathizers, common criminals, impoverished civilians, and the mentally retarded. China, even after Detachment 731 retreated in August 1945, felt the consequences for a long time after the incident. The retreat was fast, somewhat chaotic, so no one cared where

\footnotetext{
${ }^{4}$ For those who are interested in the topic of the use of BO in the Korean War, I advise you to read Supotnitsky's article in the newspaper "Tomorrow" No. 1,2 (528 and 529) from 1 and 7.01.2004

${ }^{5}$ His museum features a model of what he says is an American bacterial bomb used during this conflict.

${ }^{6}$ https://ja.wikipedia.org/wiki/憲兵_(日本軍)
} 
rodents, livestock, and other infected people were running to pathogens are organisms, namely, they caused local outbreaks of plague ${ }^{1}$ until the 1950s [51]. But, in addition to biological weapons, the Japanese army has thrown out a large number of chemical weapons in China, causing enormous damage to the environment, so chemical weapons secretly buried by the Japanese army are constantly being discovered, which leads to incidents with injuries to people and/or livestock. In this regard, a memorandum on the handling of abandoned chemical weapons was signed between China and Japan in 1999, and the countries began to destroy abandoned chemical weapons [53].

\section{Japan}

Japan, of course, is the country that bears full responsibility for the crimes of the biological weapons detachments, but even realizing this fact, it is impossible and/or, at least, very problematic to give an unambiguous assessment of the results for the Japanese state.

So, for Shiro Ishii, the chief ideologue of the bacteriological doctrine of the Japanese Empire, the head of unit 731, everything turned out extremely successfully. Ciro received immunity from prosecution from Douglas MacArthur ${ }^{2}$ on the recommendation of Charles Willoughby ${ }^{3}$ for providing detailed research materials $[54,55,56]$.

Comrade Shiro, Masaji Kitano, everything turned out extremely well, more than one Ishii was honored on his laurels. Masaji Kitano, a lieutenant general who served in the 731 squadrons, became the founder, together with Nato Reichi ${ }^{4}$, and later director of Green Cross Corporation (GCC) ${ }^{5}$. GCC in 1950, it became the first commercial blood blood bank in Japan, and later became a diversified pharmaceutical company whose specialization was research on blood clotting, immunoglobulin, and albumin, etc. In addition to all this, Masaji was also a member of the First Antarctic Social Committee, this committee sent scientific expeditions to the South Pole, but that's not all, Masaji also managed to sit in the chair of the Minister of Education [57].

And the Japanese post-war government for a long time did not admit either that it was guilty of the crimes committed, or even the fact of the existence of "death squads". In 1997, 180 Chinese, directly or indirectly affected by 731 detachments, filed a lawsuit against the Japanese government, demanding full disclosure of the facts about the activities of the detachment, an apology, and compensation, totaling 1.8 billion yen [58]. But the Japanese government ignored it and only five years later, gathering dust in the archives of Tokyo, the lawsuit was considered by the court and only then, officially, the world community was provided with all the information about the sins of the Japanese Empire and its "victorious march" across Asia. In that courtroom, Japan was found guilty of aggressive and

\footnotetext{
${ }^{1}$ As a result of cholera, anthrax, and plague, at least 400,000 Chinese civilians died [52].

${ }^{2}$ https://en.wikipedia.org/wiki/Douglas_MacArthur

${ }^{3}$ https://en.wikipedia.org/wiki/Charles_A._Willoughby

${ }^{4}$ https://ja.wikipedia.org/wiki/内藤良一

${ }^{5} \mathrm{http}: / /$ globalgreencross.com/eng/index.do
}

expansionist policies, the use of biological weapons, and the murder of Chinese civilians, but in the same courtroom 103 judges of the Tokyo District Court rejected a claim for an apology and compensation from 180 Chinese, citing, quote [59]:

'There are no legal grounds for the plaintiffs' claim, since all compensation issues were settled by an agreement with China in 1972"

Everyone knows that the Japanese economic miracle of the 1950s-1973 was caused by many factors, among which science played a significant role, it became one of the "pillars" of Japan's future economic greatness. Thus, Japanese medical science was built at the expense of "dirty" data-at least 700 doctors responsible for the terrible experiments of biological detachments received the highest awards for scientific achievements, publishing more than 100 articles in which they hid the true nature of their experiments, referring to "Korean monkeys", "Chinese monkeys", etc. [60]. For example, Dr. Hisato Yoshimura, who froze prisoners to death, advised the Japanese polar expedition [61], and one of the graduates of Detachment 1644, Masami Kitaoka, continued to experiment with unwanted Japanese subjects from 1947 to 1956, working at the National Institute of Medical Sciences of Japan. He infected the prisoners with rickettsia, and the mentally illtyphus [62].

Other criminals who started a "new" life after the war and joined Japanese medical organizations (Takeda Pharmaceutical Company Limited, Hayakawa Pharmaceutical, S. A. J Co. Ltd), became heads of medical schools or worked in ministries, I presented in the diagram below.

As it was said at the beginning, the ambiguous outcome does not allow us to say whether these events are good or bad for Japan. On the one hand, two nuclear bombs in 1945, the occupation by the troops of the United States of America from 1945 to 1952, and on the other hand, invaluable information that practically no one in the world had, innovative developments, medical and economic breakthroughs. 


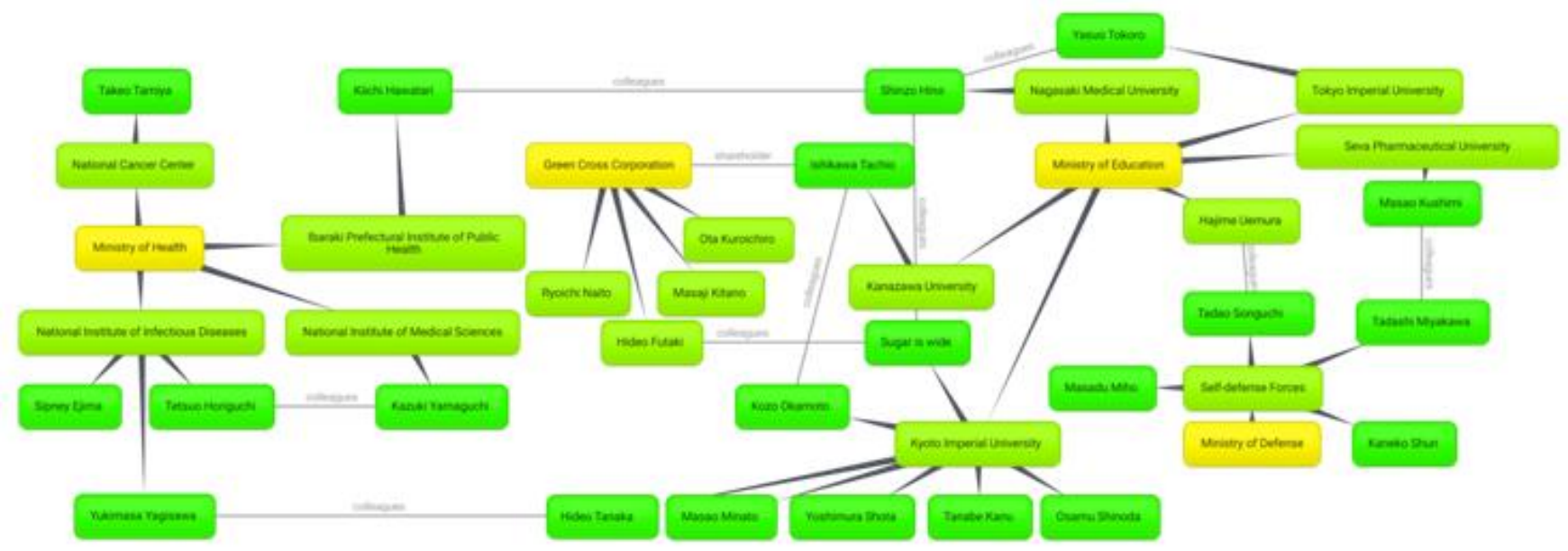

\section{Conclusion}

In conclusion of the study, I would like to say that the experiments unprecedented in their cruelty, surpassing even some Nazi atrocities, of Detachment 731 and the like, influenced people's biographies, the world of politics, and even culture.

\section{References}

[1] Morimura S. Akuma no Hoshoku [The Devil's Gluttony], 1983.-17p.

[2] Государственное издательство политической литературы. Материалы судебного процесса по делу бывших военнослужащих японской армии, обвиняемых в подготовке и применении бактериологического оружия, 1950.-8p.

[3] Государственное издательство политической литературы. Материалы судебного процесса по делу бывших военнослужащих японской армии, обвиняемых в подготовке и применении бактериологического оружия, 1950.-284p.

[4] Государственное издательство политической литературы. Материалы судебного процесса по делу бывших военнослужащих японской армии, обвиняемых в подготовке и применении бактериологического оружия, 1950.-15p.

[5] Государственное издательство политической литературы. Материалы судебного процесса по делу бывших военнослужащих японской армии, обвиняемых в подготовке и применении бактериологического оружия, 1950.-354p.

[6] Martin Merino, Mario. (2021). Unit 731: Japan's Angels of Death.

[7] Государственное издательство политической литературы. Материалы судебного процесса по делу бывших военнослужащих японской армии, обвиняемых в подготовке и применении бактериологического оружия, 1950.-356p.

[8] Gold, Hal (2004). Unit 731: Testimony. Tuttle Publishing. p.157.

[9] Gold, Hal (2011). Unit 731 Testimony (1st ed.). New York: Tuttle Pub. pp.157-158.

[10] Margolin Jean-Louis.2013. Japonia 1937-1945. Wojna Armii Cesarza. Przedm. Yves Ternon. Przeł. Joanna
Paulina Rurarz, Agnieszka Rurarz. Wyd.2 popr. Warszawa: Dialog

[11] Morawiec, Arkadiusz. (2020). Jednostka 731 w literaturze polskiej [Unit 731 in Polish Literature]. "Prace Polonistyczne" vol.75 (2020), pp.145-189.

[12] В. В. Романова. От Токийского суда к Хабаровскому: из истории подготовки судебного процесса над японскими военными преступниками-бактериологами, 2015.-73p.

[13] А. В. Алепко. Хабаровский процесс 1949 года и нечеловеческие эксперименты над людьми в бактериологическом отряде № 731 японской Квантунской армии, 2019.-66p.

[14] Государственное издательство политической литературы. Материалы судебного процесса по делу бывших военнослужащих японской армии, обвиняемых в подготовке и применении бактериологического оружия, 1950.-531p.

[15] Государственное издательство политической литературы. Материалы судебного процесса по делу бывших военнослужащих японской армии, обвиняемых в подготовке и применении бактериологического оружия, 1950.-2p.

[16] Рагинский М. Ю. Милитаристы На Скамье Подсудимых. По Материалам Токийского И Хабаровского Процессов - М.: Юридическая Литература, 1985-163p.

[17] АД. П-160071. БД "Жертвы политического террора в СССР"; Книга памяти Хабаровского края.

[18] АД. П-160088. БД "Жертвы политического террора в СССР"; Книга памяти Хабаровского края.

[19] АД. П-160348. БД "Жертвы политического террора в СССР"; Книга памяти Хабаровского края.

[20] АД. П-160073. БД "Жертвы политического террора в СССР"; Книга памяти Хабаровского края.

[21] АД. П-160118. БД "Жертвы политического террора в СССР"; Книга памяти Хабаровского края.

[22] АД. П-161038. БД "Жертвы политического террора в СССР"; Книга памяти Хабаровского края.

[23] АД. П-85586. БД "Жертвы политического террора в СССР"; Книга памяти Хабаровского края.

[24] Государственное издательство политической литературы. Материалы судебного процесса по делу бывших военнослужащих японской армии, обвиняемых в подготовке и применении бактериологического оружия, 1950.-239p. 
[25] Биологи: Биографический справочник. - Киев: Наукова думка, 1984.

[26] Государственное издательство политической литературы. Материалы судебного процесса по делу бывших военнослужащих японской армии, обвиняемых в подготовке и применении бактериологического оружия, 1950.-240p.

[27]『細菌戦部隊』, 七三一研究会編, 晚聲社, 1996年

[28] 藤井志津枝（1997年），第363页

[29] BBC Horizon "Biology at War: A Plague in the Wind" (29 Oct.1984)

[30] 楊彥軍（2015年），第14页

[31] 藤井志津枝（1997年），第363页

[32] 楊彥軍（2015年），第17-21页

[33] Private Papers of Major R Peaty". Imperial War Museums. Hal Gold, Unit 731 Testimony, 2003, p.109

[34] Richard Drayton is senior lecturer in history at Cambridge University. An Ethical Blank Check British and US Mythology About the Second World War Ignores Our Own Crimes and Legitimizes AngloAmerican Warmaking 2005 Guardian Newspapers, Ltd.

[35] The Sydney Morning Herald. Asia's Auschwitz, December 17, 1994

[36] 威廉斯\&華萊士（1992年），第288页

[37] Kristof, Nicholar D. (17 March 1995). “Unmasking Horror - A special report. Japan Confronting Gruesome War Atrocity". New York Times.

[38] "旧日本軍の731部隊（細菌部隊）人体実験に 朝鮮人".

[39] Seiichi Morimura, The Devil's Gluttony, 1981

[40] Book on Japan's germ warfare crimes published.

[41] Biological Weapons Program

（页面存档备份，存于互联网档案馆）-美國科學家聯盟（FAS）2000年4月16日

[42] Wells, A. S. (2009). The A to Z of World War II: The War Against Japan

[43] The devil unit, Unit 731. 731 部隊について

[44] Buruma, Ian (4 June 2015). "In North Korea: Wonder \& Terror".

[45] "Vivisection on Filipinos admitted". The Japan Times.

[46] Materials on the Trial of Former Servicemen of the Japanese Army Charged With Manufacturing and Employing Bacteriological Weapons. Foreign Languages Publishing House. 1950.

[47] Yuki Tanaka, Hidden Horrors, Westviewpress, 1996, p.138

[48] Gow, James; Dijxhoorn, Ernst; Kerr, Rachel; Verdirame, Guglielmo (2019). Routledge Handbook of War, Law and Technology.

[49] Sheldon Harris, Factories of Death (London, Routledge, 1994).

[50] Harris, Sheldon. "Factories of Death". p.77.

[51] 東亞三國的近現代史》共同編寫委員會

(编). 《東亞三國的近現代史》香港第一版.

[52] Barenblatt, Daniel (2004). A Plague upon Humanity: The Secret Genocide of Axis Japan's Germ Warfare Operation (1 Ed.). New York: Harper. pp.163-175.
[53] Kristof, Nicholas D. "Unmasking Horror - A special report.; Japan Confronting Gruesome War Atrocity" The New York Times (1995)

[54] 扶桑社『太平洋戦争人物列伝』

[55] 青木冨貴子

石井四郎と細菌戦部隊の闇を暴く』（新潮文庫） 245-246p

[56] 林茂夫「七三一部隊」『日本大百科全書』17

[57] 東亞三國的近現代史》共同編寫委員會 (编).

《東亞三國的近現代史》香港第一版。

香港: 三聯書店（香港）.2005.

[58] 731部隊〈ななさんいちぶたい〉アジアのアウシュビッ ツ(アウシュヴィツツ)·悪魔の部隊

[59] Shane Green is The Age's Tokyo correspondent. The Asian Auschwitz of Unit 731, August 29, 2002.

[60] The Sydney Morning Herald. Asia's Auschwitz, December 17, 1994.

[61] 日本弁護士連合会『人権白書昭和 43 年版』日本弁 護士連合会、1968年、pp.126-134.

\section{List of literature}

English-language sources

[62] "Biohazard: Unit 731 and the American Cover-Up"

[63] "Interview with former Unit 731 member Nobuo Kamada". Archived from the original on November 19,2006

[64] "Vivisection on Filipinos admitted". The Japan Times.

[65] Barenblatt, Daniel (2004). A Plague upon Humanity: The Secret Genocide of Axis Japan's Germ Warfare Operation (1 Ed.). New York: Harper.

[66] BBC Horizon "Biology at War: A Plague in the Wind"

[67] Biological Weapons Program (页面存档备份, 存于互联网档案馆 ) --

美國科學家聯盟（FAS）2000年4月16日

[68] Book on Japan's germ warfare crimes published.

[69] Buruma, Ian (4 June 2015). "In North Korea: Wonder $\&$ Terror".

[70] Drea, Edward J. (2006). Researching Japanese war crimes records: introductory essays. Washington, DC: Nazi War Crimes and Japanese Imperial Government Records Interagency Working Group.

[71] Frank Dorn, Morton J. Schwartz THE SINOJAPANESE WAR, 1937-41; FROM MARCO POLO BRIDGE TO PEARL HARBOR, 1974.

[72] Gold, Hal (2004). Unit 731: Testimony. Tuttle Publishing. p.157.

[73] Gold, Hal (2011). Unit 731 Testimony (1st ed.). New York: Tuttle Pub

[74] Gow, James; Dijxhoorn, Ernst; Kerr, Rachel; Verdirame, Guglielmo (2019). Routledge Handbook of War, Law and Technology.

[75] Kristof, Nicholas D. "Unmasking Horror - A special report.; Japan Confronting Gruesome War Atrocity" The New York Times (1995)

[76] Martin Merino, Mario. (2021). Unit 731: Japan's Angels of Death.

[77] Materials on the Trial of Former Servicemen of the Japanese Army Charged with Manufacturing and Employing Bacteriological Weapons. Foreign Languages Publishing House.1950. 
[78] Morimura S. Akuma no Hoshoku [The Devil's Gluttony], 1983.

[79] Nicholas D. Kristof New York Times, March 17, 1995. "Unmasking Horror: A special report. Japan Confronting Gruesome War Atrocity"

[80] Private Papers of Major R Peaty". Imperial War Museums.

[81] Review of the studies on Germ Warfare Tien-wei Wu a Preliminary Review of Studies of Japanese Biological Warfare and Unit 731 in the United States

[82] Richard Drayton is senior lecturer in history at Cambridge University. An Ethical Blank Check British and US Mythology About the Second World War Ignores Our Own Crimes and Legitimizes AngloAmerican Warmaking 2005 Guardian Newspapers, Ltd.

[83] Seiichi Morimura, The Devil's Gluttony, 1981

[84] Shane Green is The Age's Tokyo correspondent. The Asian Auschwitz of Unit 731, August 29, 2002.

[85] Sheldon Harris, Factories of Death (London, Routledge, 1994).

[86] Takashi Tsuchiya. "The Imperial Japanese Experiments in China". The Oxford Textbook of Clinical Research Ethics, pp, 35, 42. Oxford University Press, 2011.

[87] Tanaka, Y. (1997) Hidden Horrors: Japanese war crimes in World War II, Boulder: Westview Press.

[88] The devil unit, Unit 731. 731 部隊について

[89] The Sydney Morning Herald. Asia's Auschwitz, December 17, 1994.

[90] TSUCHIYA Takashi, "Self Determination by Imperial Japanese Doctors", December 16, 2007.

[91] Wells, A. S. (2009). The A to Z of World War II: The War Against Japan

[92] Russian-language sources:

[93] «Лучше в ад!»: русские в японском лагере во время Второй мировой

[94] Бактериологическая война-преступное орудие империалистической агрессии. Хабаровский процесс японских военных преступников / Рагинский М. Ю., Розенблит С. Я., Смирнов Л. Н.; Отв. ред.: Кожевников Ф. И.-М.: Изд-во АН СССР, 1950.-135 c.

[95] Биологи: Биографический справочник. - Киев: Наукова думка, 1984

[96] В. В. Романова. От Токийского суда к Хабаровскому: из истории подготовки судебного процесса над японскими военными преступниками-бактериологами, 2015.

[97] Газета Тихоокеанская Звезда за 1949-1950 года.

[98] Государственное издательство политической литературы. Материалы судебного процесса по делу бывших военнослужащих японской армии, обвиняемых в подготовке и применении бактериологического оружия, 1950.

[99] Доклад международной научной комиссии по расследованию фактов бактериологической войны в Корее и Китае, Пекин, 1952

[100]Журнал Японского общества медицинских исследований. Декабрь 2011

[101]Звягинцев Александр Григорьевич. Главный свидетель Токийского международного военного трибунала. ИГП РАН, 2021.
[102]Каплан, А. В., 1979. Повреждение костей и суставов. Москва: Медицина.

[103]Корольков Ю. М. Кио ку мицу! Совершенно секретно - при опасности - сжечь! Романхроника. - М.: Советский писатель, 1970

[104]Кошкин А. А. «Кантокуэн» — «Барбаросса» пояпонски. Почему Япония не напала на СССР. М.: Вече, 2011

[105]Кузнецов Д. В. Оружие дьявола: Разработка и применение оружия массового уничтожения во время агрессии Японии против Китая (1931-1945 гг.). - Благовещенск: Изд-во БГПУ, 2019.

[106]Нарышкин С. Н., Торкунов А. В. (ред.) Великая Победа. Т. ІХ. Агония. М.: МГИМО (У) МИД России. РВИО, 2015

[107]Никитин, В. Апокалипсис огненной эпопеи. Трибуналы в Токио и Хабаровске (1946-1948, 1949 годы) / В. Никитин // Приамур. ведомости. - 2010 - 1 сент. (№ 129). - С.5.

[108]Пасынков, И. Н. Жизнь, отданная людям / И. Н. Пасынков // На сопках Маньчжурии. — 2008. - № 147 (нояб.). - С.2.

[109]Плискиной Валентины Николаевна РУССКИЕ ПЕРЕВОДЧИКИ ИЗ ХАРБИНА // КУЛЬТУРА И НАУКА ДАЛЬНЕГО ВОСТОКА.2019. №1 (26).

[110]Рагинский М. Ю. Милитаристы на скамье подсудимых. По материалам Токийского и Хабаровского процессов - М.: Юридическая литература, 1985

[111]Супотницкий М. В., Супотницкая Н. С. Чума от дьявола (Китай 1933-1945).

[112]Супотницкий M. B. Биологическая война. Введение в эпидемиологию искусственных эпидемических процессов и биологических поражений: монография.-М.: “Кафедра", "Русская панорама", 2013.1136с.: ил.

Japanese-Chinese sources:

[113]"旧日本軍の 731 部隊（細菌部隊）人体実験に 朝鮮人".

[114]《東亞三國的近現代史》共同編寫委員會 (编). 《東亞三國的近現代史》香港第一版. 香港: 三聯書店（香港）.2005.

[115]『細菌戦部隊』, 七三一研究会編, 晚聲社, 1996年

[116]731部隊〈ななさんいちぶたい〉アジアのアウシュビッ ツ(アウシュヴィツ)・悪魔の部隊

[117]

中国黒龍江省档案館 - 中国黒龍江省人民対外友好 協会 ·日本 $A B C$ 企画委員会編『七三一部隊罪行鉄 証関東憲兵隊「特移扱」文書』

[118]南香红.

隐姓埋名、洗白过往：731部队杀人科学家的战后 高尚生活

[119]外山操編『陸海軍将官人事総覧陸軍篇』芙蓉書房 出版、1981年。

[120]威廉斯\&華萊士（1992年），第288页

[121]常石敬一『七三一部隊生物兵器犯罪の真実』講談 社現代新書 1995年

[122]扶桑社『太平洋戦争人物列伝』 
[123]文艺春秋1983年二月号

[124]日公開731部隊錄音認罪活體實驗

[125]日暮吉延『東京裁判』, 2008

[126]日本弁護士連合会『人権白書昭和 43 年版』日本弁 護士連合会、1968年

[127]日軍曾在廣州拿活人做實驗

[128]東亞三國的近現代史》共同編寫委員會 《東亞三國的近現代史》香港第一版.

(编).

[129]林茂夫「七三一部隊」『日本大百科全書』17

[130] 楳本捨三将軍の四季最後の関東軍総司令官山田乙 三大将. 潮書房光人新社, 1983.

[131]田中明、松村高夫（編）『十五年戦争極秘資料集 29 七三一部隊作成資料』不二出版、1991年

[132]田辺敏雄『検証旧日本軍の「悪行」一歪められた 歴史像を見直す』自由社、2002年

[133] 福川秀樹『日本陸軍将官辞典』芙蓉書房出版、20 01 年。

[134]秦郁彦『昭和史の謎を追う 』文春文庫、1999年

[135]秦郁彦編著『日本陸海軍総合事典』（第2版） 東京大学出版会、2005年

[136]藤井志津枝（1997年），第363页楊彥軍2015年

[137]豊原亮モトカントウグングンイブチョウカジズカ リュウジノハンセイ :

ソビェトヨクリュウノシンソウニッイテ. 宮城県医師会報

[138] 逃出七三一萨苏, 《尊严不是无代价的：从日本史 料揭秘中国抗2009

[139]青木冨貴子 石井四郎と細菌戦部隊の闇を暴く

[140]Polish sources:

[141]Jednostka $731 \mathrm{w}$ literaturze polskiej [Unit 731 in Polish Literature]. "Prace Polonistyczne" vol.75 (2020), pp.145-189.

\section{Electronic sources:}

[142] http: //evolutio. info/ru/journal-menu/2009-3/2009-3barishev

[143] http: //kuznetsov. ucoz. org/books/CHINA_2017. pdf

[144]http: //travma-ro, ru/informatsiya/biblioteka/himioterapiya-ranevoyinfektsii-v-travmatologii-i-ortopedii-v-m-melnikovamoskva-meditsina-1975/1070-2/

[145]http: //www.chinadaily. com. cn/en/doc/200310/17/content_273165. htm

[146]http: //www.deepblacklies. co. uk/unit731-part1. htm

[147]https: //benhills. com/articles/the-war/inside-japanswartime-factory-of-death/ [148]https: //fepow-community. org.
uk/arthur_lane/html/biological_warfare_unit_731_in. $\mathrm{htm}$

[149]https: //histrf. ru/biblioteka/SovietNuremberg/Khabarovsky-process

[150]https: //meduniver. com

[151]https: //ru. openlist. wiki/Открытый_список: Заглавная_страница [152]https: //thoracickey. com/heart-and-thoracic-vascularinjuries/

[153] https: //web. archive. org/web/20170817164023/http: //dajia. qq. com/original/category/nxh20170816. html

[154]https: //www.iwm. org. uk/collections/item/object/1030006245

[155]https: //www.npr. org/2011/04/25/135638924/whereto-find-the-worlds-most-wicked-bugs

[156]https: $\quad$ //www.theguardian. com/world/2018/apr/17/japan-unit-731-imperial-armysecond-world-war 